Original Research Paper

\title{
Peran Pemerintah Terhadap Perekonomian Masyarakat Desa Pada Saat Pandemi Covid-19 (Studi di Desa Dasan baru Kopang Kabupaten Lombok Tengah)
}

\author{
Pahrizal Iqrom $^{*}$ Wisma Widiana Patmil $^{2}$, Hisbullah $^{3}$, Aditya $^{4}$, Hartika $^{5}$ \\ ${ }^{1}$ Program Studi Administrasi Negara, Universitas Nahdlatul Wathan Mataram, Indonesia \\ 2,Mahasiswa Program Studi S1 Pendidikan Agama Islam, Universitas Nahdlatul Wathan Mataram, Indonesia \\ ${ }^{3}$ Mahasiswa Program Studi S1 Ilmu Administrasi Negara, Universitas Nahdlatul Wathan Mataram, Indonesia \\ ${ }^{4}$ Mahasiswa Program Studi S1 Pendidikan Agama Islam, Universitas Nahdlatul Wathan Mataram, Indonesia \\ ${ }^{5}$ Mahasiswa Program Studi S1 Ilmu Hukum, Universitas Nahdlatul Wathan Mataram, Indonesia
}

https://doi.org/10.29303/jpmpi.v3i2.1028

Sitasi: Iqrom, P., Patmil, W. W., Hisbullah., Aditya \& Hartika. (2021). Peran Pemerintah Terhadap Perekonomian Masyarakat Desa Pada Saat Pandemi Covid-19 (Studi di Desa Dasan baru Kopang Kabupaten Lombok Tengah). Jurnal Pengabdian Magister Pendidikan IPA, 4(4)

\section{Article history}

Received: 20 September 2021

Revised: 30 September 2021

Accepted: 10 Oktober 2021

*Corresponding Author:

Pahrizal Iqrom, Program

Studi Administrasi Negara,

Fakultas Ilmu Administrasi

Universitas Nahdlatul Wathan

Mataram, Indonesia;

Email:

pahrizaliqrom@gmail.com

\begin{abstract}
Abstrak: Salah satu kunci dalam meningkatkan Produktifitas Pendapatan Masyarakat adalah dengan membuka ruang transaksi jual-beli pada UMKM. Melalui interaksi antar masyarakat tersebut maka tercipta tawarmenawar untuk satu kebutuhan dalam rumah tangga. Lalu bagaimana jika Pandemi membatasi akses UMKM Masyarakat untuk berkembang?. apakah kebijakan yang akan di keluarkan oleh pemerintah telah berpihak terhadap Pelaku UMKM atau sebaliknya malah merugikan?. Sebuah Survei bersekala Nasional yang dilakukan pada akhir Tahun 2020, Kolaborasi antara UNICEF, UNDP, Prospera dan The SMERU Research Institute memberikan gambaran bahwa Pemerintah Indonesia belum siap dalam menghadapi pandemi Covid-19 secara Maksimal. Karena itu dibutuhkan upaya lebih. Fenomena tersebut berdampak pada UMKM. Masalah yang muncul di antaranya; 1. Banyaknya Informasi Yang Membingungkan dan Hoax Yang Beredar meredahkan masyarakat terhadap ketahanan pangan mereka., 2. Kepedulian Tinggi Namun Masih Belum Paham Apa Yang Akan Dilakukan dalam upaya membantu masyarakat sekitarnya yang lebih terpapar., 3. Diskriminasi, Stigma, dan Pengucilan Terhadap Pasien Covid-19 dan Keluarganya menyebabkan keputusasaan., 4. Kebutuhan pengan masyarakat dikhawtirkan lebih banyak dari sebelumnya karena masyarakat tidak memilki sumber penghasilan lagi., 5. Banyak Komoditi pertanian yang tidak bisa terjual ke pasar sehingga merugikan masyarakat.
\end{abstract}

Keywords: Pemerintah, Budaya Organisasi, Kesejahteraan Masyarakat

\section{Pendahuluan}

$\mathrm{M}$ erebaknya wabah meneguhkan panggilan bagi para pekerja kemanusiaan untuk semakin berkolaborasi secara interdisiplin, agar mendapatkan solusi yang paling komprehensif dan tepat. Covid-19 memang wilayah ilmu kedokteran dan kesehatan. Namun dampaknya yang dahsyat telah mengubah kehidupan global di segala bidang; menandakan kompartementalisasi bidang ilmu sudah usang.

Kebutuhan masyarakat menjadi pendorong utama munculnya ilmu lintas disiplin. Sayangnya kelimpahan informasi terkait wabah Covid19 kurang memperhitungkan suara ilmu sosial- 
humaniora. Padahal dampak wabah terhadap kemanusiaan dan kemasyarakatan menyiratkan soal keadilan sosial. Ketika mengalami ketidakpastian sosial karena terhentinya penghasilan sebagian atau seluruhnya. Bagi para relawan Berbagai pertanyaan kerapkali naik keatas permukaan, antara lain;

1. siapakah kelompok yang aksesnya paling rentan terhadap hak kesehatan dan kelangsungan hidup ?

2. Mampukah pengambil kebijakan mengidentifikasi mereka yang harus diutamakan untuk ditolong?

3. Bagaimana kolaborasi antar ilmu pengetahuan bisa membantu mengurangi dampak pandemi terhadap pertumbuhan UMKM?

4. Bagaimanakah Kebudayaan Baru akan terbentuk?

Serangan Covid-19 akan mengubah dunia dalam hal cara berpikir dan berpengetahuan, cara hidup, dan cara berhukum atau penentuan apa yang boleh dan tidak boleh.

Itulah esensi kebudayaan. Setiap orang (potensial) terdampak Covid-19, sehingga wabah bukan lagi masalah orang per orang, tetapi komunitas, masyarakat bahkan bangsa. Setiap orang memproduksi dan mendistribusi kegelisahan, ketakutan, kecemasan dan ketidakpastian; maka terbentuklah pengetahuan dan pengalaman kolektif.

Banyak inisiatif, dan solidaritas kolektif dari komunitas dan jejaring dalam masyarakat bertujuan mengupayakan perlindungan bersama dalam berbagai bentuk donasi dan kerjasama. Covid-19 telah menyatukan gagasan dan kerjasama kolektif secara bermakna, dan besar kemungkinan melahirkan kebudayaan baru terkait cara hidup sehat.

Masyarakat memiliki kapasitas untuk itu, terlepas dari hadir atau tidaknya negara. Cara berpengetahuan adalah bagian dari esensi kebudayaan. Pasca Covid-19 yang memberi pembelajaran besar, diramalkan akan melahirkan percabangan ilmu baru interdisiplin, yang semakin intensif. Dalam kolektiva keilmuan baik kampus maupun pusat riset industri, para ilmuwan akan berusaha mencari solusi yang paling tepat untuk mengatasi wabah. Ilmu kesehatan dan keteknikan klasik saat ini sudah memunculkan percabangan ilmu baru seperti life sciences, bio-molecular science, biomedical science, bioinformatics dengan berbagai percabangannya; dan akan menghasilkan obat, vaksin dan alat-alat pendeteksi dan penyembuh.

Sementara llmu matematik-statistik bersama ilmu aplikasinya seperti ilmu komputer, melahirkan ilmu baru seperti data science, dan menghasilkan berbagai produk artificial intelligence yang potensial menggantikan atau mendukung profesi banyak bidang, termasuk kedokteran. Nantinya perkembangan ilmu-ilmu interdisiplin akan semakin luas dan menghasilkan kebudayan material baru, termasuk digital, yang mencengangkan. Meskipun globalisasi mungkin akan didefinisi ulang karena ditenggarai penyebaran Covid-19 disebabkan mobilitas dan konektivitas orang dan barang secara masif. Namun globalisasi dengan karakter baru dengan basis konektivitas digital tidak akan surut ke belakang.

Melihat kondisi tersebut para ilmuwan sosial humaniora, dan ahli statistik seharusnya mampu mencari solusi, bagaimana cara menentukan kelompok paling rentan. Para ekonomi bisa menghitung kerugian dari kesalahan kebijakan akibat ketidakmampuan mengidentifikasi mereka yang paling rentan. Kita juga menantikan badanbadan dunia dan komunitas ilmuwan membuat platform bersama untuk mengatasi wabah global.

\section{Metode}

Jenis penelitian yang digunakan penulis dalam penelitian ini adalah metode penelitian deskriptif kualitatif. Menurut Nawawi (1990:64) bentuk deskriptif adalah bentuk penelitian yang memusatkan pada masalah-masalah atau fenomenafenomena yang bersifat akual pada saat penelitian dilakukan, kemudian menggambarkan fakta-fakta tentang masalah yang diselidiki sebagaimana adanya diiringi dengan interpretasi yang rasional dan akurat.

Adapun jenis data yang penulis peroleh dalam penelitian lapangan ini adalah data perimer dan data sekunder yang bersifat kualitatif. Sedangkan dalam penelitian ini, penulis melakukan teknik pengumpulan data dengan beberapa cara diantaranya: dokumen kuesioner, Wawancara, pengamatan, buku dan dari halaman web.

Teknik analisis data yang dipergunakan dalam penelitian ini dengan menggunakan teknik kualitatif. Menurut Farid (1997:152) bahwa analisa kualitatif adalah analisa terhadap data yang diperoleh berdasarkan kemampuan nalar peneliti 
dalam menghubung-hubungkan fakta, data dan informasi.

\section{Hasil dan Pembahasan \\ 1. Pemerintah}

Menurut Mac Iver (dalam Inu Kencana, 2005:34) mengartikan Pemerintah itu sebagai suatu organisasi yang mempunyai kekuasaan (government is the organization of men under authorization). Sedangkan W.Sayre (dalam Muhadam 2006:17) Pemerintah merupakan gejala yang memperlihatkan dan menjalankan kekuasaan Negara.

Inu kencana (2005:20) mengartikan bahwa Pemerintah dalam arti luas adalah keseluruhan kegiatan Pemerintah, baik menyangkut, legislatif, eksekutif, maupun yudikatif. Sedangkan Pemerintah dalam arti sempit yaitu kegiatan Pemerintah yang hanya menyangkut eksekutif.

Adanya kewenangan penuh dalam pengelolaan wilayahnya sendiri maka disini Pemerintah Desa memiliki hak dan kewajiban untuk mengembangkan Desa yang memiliki UMKM khusunya. Dengan demikian Pemerintah Desa melalui Otonomi Khusus mempunyai kewajiban untuk pengelolaan sumber daya alam, menyediakan infrastruktur, sarana dan prasarnan yang memadai. Dengan adanya pengelolan UMKM yang optimal maka Pemerintah dapat menyediakan lapangan pekerjaan sehingga dapat memperkecil angka pengangguran dan juga pendapatan Desa akan bertahan di masa pandemi saat ini.

Di Desa Dasan Baru, Kopang Kabupaten Lombok Tengah terdapat 8 Lembaga Perekonomian Seperti Bumdes, Lembaga Keuangan Non Bank, Rumah makan dan restoran, Angkutan antar Kota/Provinsi, Usaha Jasa dan Perdagangan, Industri Hiburan, Pengecer gas dan bahan bakar Minyak, dan Usaha jasa keterampilan.

\section{Budaya Organisasi}

Pengertian tentang budaya (culture) berasal dari Hofstede (1994). Beliau menyatakan bahwa budaya merupakan "keseluruhan pola pikir, perasaan, dan tindakan dari sesuatu kelompok sosial, yang membedakan dengan kelompok sosial yang lain". Beliau juga mengatakan bahwa istilah the colective mental programing atau soft ware of the mind digunakan untuk menyebutkan seluruh pola dalam kajian budaya.
Budaya suatu kelompok terbentuk oleh lingkungan sosial, (seperti negara, daerah, tempat kerja, sekolah dan rumah tangga) dan kejadiankejadian yang dialami dalam kehidupan para anggota kelompok yang bersangkutan. Kemudian proses terbentuknya pola pikir, perasaan dan tindakan itu dianalogikan dengan proses penyusunan program komputer. Budaya sendiri dapat dikelompokan dalam berbagai tingkatan antara lain : nasional,daerah, gender, generasi, kelas sosial, organisasi atau perusahaan.

Hoftede (1994) mengembangkan kerangka pengukuran budaya positif, beliau melacak berbagai jenis budaya di 40 negara dimana IBM beroperasi dengan menggunakan wawancara terstruktur. Selanjutnya dengan teknik statistika multivariat analisis faktor, beliau menggabungkan berbagai variable-variable tersebut menjadi 4 dimensi budaya nasional meliputi: power distance, colectivism/individualism,masculinity/feminity dan uncerttainty avoidance.

Dari 8 sektor ekonomi yang ada, hanya Usaha jasa dan Perdagangan yang masih bertahan untuk memenuhi kebutuhan hidup dari 13.066 orang. Ditengah pandemi, keberpihakan menjadi barang langka karena akses perekonomian yang terputus oleh kebijakan pemerintah. Sehingga Keberlanjutan UMKM juga menjadi prioritas penting yang diselamatkan di tengah pandemi virus corona atau Covid-19. Karena peran pelaku UMKM di tengah krisis atau wabah untuk tetap menjaga bergeraknya sektor riil di tanah air menjadi sangat penting. Hal ini menjadi sebuah tantangan yang besar di Desa karena Krisis pangan telah benar-benar terjadi di berbagai belahan dunia. Ditandai dengan melonjaknya harga-harga pangan dunia seperti makanan pokok berupa gandum, kedelai, beras, dan jagung. Penurunan pasokan berdampak pada harga pangan di pasar dunia semakin melambung, sehingga mengakibatkan masyarakat miskin harus membayar lebih mahal dibandingkan orang kaya di negara maju.

\section{Kesejahteraan Masyarakat Desa}

Menurut Walter A. Friedlander (1961) "Kesejahteraan masyarakat desa adalah sistem yang terorganisir dari pelayanan-pelayanan sosial kemasyarakatan dan lembaga-lembaga yang bertujuan untuk membantu individu dan kelompok untuk mencapai standar hidup dan kesehatan yang memuaskan dan relasi-relasi pribadi dan sosial 
yang memungkinkan mereka mengembangkan kemampuannya sepenuh mungkin dan meningkatkan kesejahteraannya secara selaras dengan kebutuhan keluarga dan masyarakat".

Pembangunan infrastruktur jalan yang mempunyai tingkat produktivitas yang tinggi merupakan potensi sumber daya manusia yang sangat dibutuhkan dalam proses pembangunan meyongsong era globalisasi yang telah dihadapi oleh Indonesia saat ini. Jalan memberikan peran yang sangat penting bagi peningkatan kesejahteraan masyarakat dan produktivitas yang tinggi bagi pertumbuhan ekonomi itu sendiri, sehingga akan diperoleh kapasitas produktif dari sumber daya manusia, serta diperolehnya penigkatan kesejahteraan masyarakat itu sendiri.

Selain itu, ketahanan pangan dalam masa pendemi covid-19 ini dapat kita artikan sebagai keterjangkauan pangan yang juga berkaitan erat dengan upaya peningkatan mutu sumberdaya manusia Indonesia. Tanpa dukungan pangan yang cukup dan bermutu, tidak mungkin dihasilkan sumberdaya manusia yang bermutu dan kesehatan yang bermutu pula, oleh karena itu membangun sistem ketahanan pangan yang kokoh merupakan syarat mutlak bagi pembangunan nasional dan ketahanan dalam menghadapi situasi saat ini.

Sejarah membuktikan bahwa ketahanan pangan sangat erat kaitannya dengan ketahanan sosial, stabilitas ekonomi, stabilitas politik umum, ketahanan pangan yang rapuh akan memicu terjadinya konflik. Badan Pangan Dunia (FAO), mengatakan bahwa kelangkaan pangan yang disusul melambungnya harga telah memicu kerusuhan, antara lain di berbagai Negara seperti Mesir, Kamerun, Haiti, dan Burkina Faso, yang tentunya kita tidak inginkan hal tersebut terjadi disini. Karena ketersediaan pangan yang cukup secara nasional ternyata juga tidak menjamin adanya ketahanan pangan tingkat wilayah (regional), pedesaan, serta rumah tangga individu. Hal ini ditunjukkan antara lain dari studi yang dilakukan oleh Saliem et al. (2005).

Terkait dengan fakta tersebut maka masalah bagaimana mengelola ketersediaan pangan yang cukup tersebut agar dapat diakses oleh rumah tangga individu di masing-masing wilayah desa merupakan isu menarik untuk ditelaah dan dikembangkan menjadi sumber ketahanan masyarakat. Pengelolaan pangan terkait dengan masalah bagaimana mengelola cadangan pangan dan eningkatan nilai jual, serta manajemen cadangan pangan merupakan salah satu aspek yang belum banyak dikaji secara baik.

\section{Kesimpulan}

Setelah melalui tahap kajian, maka diperolehlah kesimpulan sebagai berikut:

1. Pemerintah belum serius Memutus Rantai Penyebaran Covid_19

2. Pemerintah Desa mengalami disorientasi Dalam Mempercepat Pemulihan ekonomi masyarakat karena tersandera oleh Kebijakan Pemerintah Pusat yang sentralistik

3. Belum adanya inisiatif untuk Membangun Mekanisme Pemasaran Lokal di Lingkungan Desa

4. Belum terlihat langkah kongkrit untuk Memaksimalkan Hasil Produksi pertanian dan peternakan

5. Disisi yang lain pemerintah Desa belum memiliki strategi kusus dalam Membangun Skema pemasaran produksi komoditi unggulan bagi Masyarakat yang memiliki komoditas

6. Tindakan pemerintah desa masih lemah dalam Memberikan Pemerataan Komunikasi, Informasi,dan Edukasi Kepada Masyarakat

7. Diperparah dengan ketidakmampuan pemeerintah Desa dalam Menekan Stigma Yang Berkembang di Masyarakat

8. Masyarakat Desa masih enggan untuk Mendukung Pemerintah Dalam Menurunkan Kasus Penularan

9. Meskipun Kampaye Prilaku Hidup Bersih dan Sehat Berkelanjutan terus dilaksanakan namun tidak mampu menjawab persoalan dasar yakni mengurangi stigma Negatif keberadaan Covid19, sehingga masyarakat terkesan abai terhadap himbauan Pemerintah.

10. Meskipun Pemerintah terus Mendorong Keterlibatan Mayarakat dalam Memutus rantai Penularan namun respon balik dari masyarakat masih lemah

11. Langkah cepat yang dilakukan oleh Pemerintah desa sudah bagus yakni Mendorong Pengerahan Pilar-Pilar Sosial di Masyarakat

12. Sejauh ini telah ada upaya Menyiapkan Perlindungan untuk Kelompok Rentan dan Bantuan Sosial namun belum tetap sasaran seutuhnya. 


\section{Ucapan Terima Kasih}

Tim pengabdian pada masyarakat menyampaikan ucapan terima kasih kepadaKepala Desa Dasan baru Kecamatan Kopang Kabupaten Lombok Tengah yang telah bersedia untuk di Evaluasi dan kooperatif dalam setiap aktivitas pengabdian yang kami laksanakan. Terima kasih juga kami sampaikan kepada Universitas Nahdlatul Wathan yang telah memberikan ruang sehingga kegiatan pengabdian pada masyarakat ini dapat kami laksanakan.

\section{Daftar Pustaka}

Ali, Faried. 1997. Metode Penelitian Sosial Dalam Bidang Ilmu Administrasi. Jakarta : PT. Raja Grafindo Persada.

A Friedlander, Walter. 1961 . Pengantar Kesejahteraan Sosial Jakarta: Gema Insani Press.

Bintarto. 1989. Interaksi Desa Kota dan Permasalahannya. Ghalia Indonesia. Jakarta.

Hofstede, G. (1994). Cultures and organizations: software of the mind. London: Harper-Collins Publishers.

Mac Iver dalam Syaffie, Kencana ,Inu. 2005. Pengantar Ilmu Pemerintahan. Bandung. PT Refika Aditma

Miles, Matthew B. dan A. Michael Huberman. 1992. Analisis Data Kualitatif. Diterjemahkan oleh Tjetjep Rohendi Rohidi. Jakarta: Penerbit Universitas Indonesia.

Nawawi. 1990. Metode Penelitian Sosial. Yogyakarta: UGM Press.

Syaffie, Kencana ,Inu. 2005. Pengantar Ilmu Pemerintahan. Bandung. PT Refika Aditma

Saliem, H.P., Purwoto, A., Hardono, G.S., Purwantini, T.B., Supriyatna, Y., Marisa, Y. dan Waluyo. 2005. Manajemen Ketahanan Pangan Era Otonomi Daerah dan Perum Bulog. Jakarta: PSEKP-Badan Penelitian dan Pengembangan Pertanian, Departemen Pertanian
Undang-Undang No 23 Tahun 2014 Tentang Pemerintahan Daerah

Undang-Undang Nomor 6 Tahun 2014 tentang Pemerintahan Desa

W. Sayre dalam Labolo. Muhadam. 2070. Memahami Ilmu pemerintahan. Jakarta: Rajawali Press. 